\title{
Etika Agama di Tengah Krisis Moral Bangsa
}

\author{
Alois A. Nugroho \\ Guru Besar etika dan filsafat Unika Atma Jaya, Jakarta
}

\begin{abstract}
Our nation moral crisis is closely related to our incapability to do what so-called "expanding the circle" in the moral deliberation today. The corruptors and black merchants in some way are the people who want to "feed" their family, and it means also the "extended family". So, we are too naive if judge them as a group of egoistic people. Yet, we can say that they suffer a moral "myopia". Their solitude horizon is very narrow. They only think the goodness of their near surrounsings. Their horizon does not reach the "nation area" or "national interest", let alone "human being" and "the future of people," "ecological care."
\end{abstract}

Kata Kunci: etika; kesadaran; kepedulian

\section{Pendahuluan}

Dalam acara tasyakuran peringatan Hari Amal Bhakti ke-63 Departemen Agama tahun 2009 di Pekan Raya Jakarta, 17 Januari 2009, Menteri Agama Republik Indonesia menyimpulkan adanya keyakinan publik bahwa di Indonesia telah terjadi krisis moral dan etika keagamaan. Menurut Menag, meski belum pernah dilakukan penelitian tentang kebenaran klaim tersebut, tetapi secara "common sense", opini itu telah terlanjur diyakini masyarakat sebagai suatu kebenaran.

Bagi observasi rakyat biasa yang berpartisipasi dalam kehidupan biasa, sebenarnya tidak sukar mengumpulkan berita-berita yang dapat mendukung "common sense" itu. Bagi sementara kalangan, video mesum mirip Ariel dengan Luna Maya atau dengan Cut Tari menjadi salah satu bukti bahwa telah terjadi krisis moral bangsa, karena kasus itu menunjukkan bahwa sebagian masyarakat menganggap perzinahan dan perselingkuhan sebagai tindakan lumrah. Efek video itu pun lebih lanjut akan mempengaruhi mo- ralitas pihak-pihak yang masih mempertahankan etika agama serta anak-anak yang belum mengenal budaya perselingkuhan.3 Kasus video "Bandung Lautan Asmara" tahun 2001 terulang sembilan tahun kemudian dan terasa lebih heboh karena melibatkan para selebritas yang sedang bersinar. Ditam- bah dengan berita kawin cerai dan perilaku seksual para selebritas, termasuk para "selebritas politik", "selebritas intelektual" dan "selebritas agama", publik menangkap bahwa kasus video porno hanyalah puncak dari gunung es yang besar.

Meski dampak sosialnya tidak kecil, namun krisis moral di atas sering dika- tegorikan sebagai krisis dalam kaitannya dengan "kesalehan pribadi". Lebih lanjut, banyak pula pihak yang lebih prihatin pada krisis moral dalam kait- annya dengan "kesalehan publik", semisal yang mencuat dalam bentuk korupsi, kesenjangan kaya miskin dan memudarnya toleransi.

Indonesia yang disebut-sebut sebagai salah satu bintang negara emerging markets ternyata merupakan negara terkorup dari 16 negara tujuan investasi di Asia Pasifik. Demikian hasil survei bisnis yang dirilis Political \& Economic Risk Consultancy atau PERC. Dalam survei tahun 2010, Indonesia menem- pati peringkat pertama sebagai negara terkorup dengan mencetak skor 9,07 dari nilai 10. Posisi kedua ditempati Kamboja, kemudian Vietnam, Filipina, Thailand, India, China, Malaysia, Taiwan, Korea Selatan, Makao, Jepang, Amerika Serikat, Hongkong, Australia, dan Singapura sebagai negara yang paling bersih.4 Dalam peringkat 
Konfrontasi: Jurnal Kultur, Ekonomi dan Perubahan Sosial, 3 (1) Januari 2016, 24-28

P-ISSN: 1410-881X (Print)

\section{Alois A. Nugroho, Etika Agama di Tengah Krisis Moral Bangsa \\ DOI: - \\ http://www.konfrontasi.net/index.php/konfrontasi2}

angka mulai dari 0 (negara terbersih) hing- ga 10 (negara terkorup), "perolehan" Indonesia meningkat dari 7,98 pada 2008 dan 8, 32 pada 2009 menjadi 9,07 pada 2010.

Kesahihan temuan PERC memang dapat diperdebatkan. Namun kasus "Cicak vs Buaya" akhir tahun 2009 yang mengalami ramifikasi dan over- lapping menjadi "Kasus Makelar Kasus", "Kasus Bank Century", "Kasus Mafia Peradilan", "Kasus Rekening Gendut para Petinggi Polisi", "Kasus Gayus", "Kasus Makelar Pajak", "Kasus foto turnamen tennis", bersama dengan "kasus Deputi Gubernur BI" dan kasus-kasus lain yang menimpa parlemen, birokrasi, aparat hukum dan para politisi, hanya mengukuhkan hasil temuan PERC. Badan-badan eksekutif, legislatif dan yudikatif kita telah ternoda.

Dalam hal kesenjangan kaya miskin, angka kemiskinan pada 2010 menurut perhitungan Badan Pusat Statistik yang lazimnya lebih optimistis pun, tidak banyak beranjak jauh dari angka kemiskinan pada 2009. Angka Kemiskinan di Indonesia pada Maret 2010 mencapai 31,02 juta (13,33 persen), turun 1,51 juta dibandingkan dengan penduduk miskin pada Maret 2009 yang sebesar 32,53 juta (14,15 persen).5 Mereka yang tergolong miskin menurut BPS ialah mereka yang pengeluaran per kapita kurang dari Rp. 211.726,-- per bulan atau Rp.7.000,-- per hari. Sementara itu, kelompok dengan penge-luaran 10- 20 USD (Rp. 90.000,-- - Rp. $180.000,--)$ per kapita per hari naik dari 0,4 juta orang pada 2009 menjadi 2,23 juta orang pada 2009.

Sementara itu, kalangan lain menunjukkan memudarnya moralitas "bhineka tunggal ika" sebagai salah satu bukti adanya krisis moral itu. Pada Oktober 2010, Lingkaran Survei Indonesia mengumumkan hasil temuannya bahwa tingkat toleransi atas keberagaman berdasarkan paham Bhinneka Tunggal Ika menurun drastis. Sebaliknya, pembenaran kekerasan dengan mengatas- namakan agama meningkat secara signifikan. Untuk melihat sejauh mana toleransi tersebut, LSI mengajukan pertanyaan kunci tentang kekerasan yang dialami Ahmadiyah. Dari hasil survei per September 2010, sebanyak 30,2 persen responden menyetujui kekerasan terhadap Ahmadiyah. Hasil ini jauh meningkat dibandingkan hasil survei tahun 2005 yang hanya 13,9 persen.

Tidak mudah menguraikan benang kusut dalam kehidupan berbangsa ini. Biasanya, dikatakan bahwa harapannya terletak pada pendidikan. Namun, pendidikan bukan hanya apa yang diajarkan melalui kata-kata atau melalui tindakan-tindakan yang disengaja. Tindakantindakan yang tidak disengaja, yang dijalankan sebagai kebiasaan, yang tidak direfleksi, juga merupakan "kurikulum pendidikan" yang tak disadari, merupakan "kurikulum tersem- bunyi", maksudnya tersembunyi dari kesadaran kita sendiri. Di sini kita akui kelemahan etika sebagai pemikiran tentang norma-norma atau kewa-jiban- kewajiban, karena pemikiran tentang normanorma atau kewajiban- kewajiban itu pun didorong oleh gairah hidup yang menggelegak sejak dalam ketidaksadaran. Kita mungkin punya façade yang kita sembunyikan dari sorot mata orang lain, apa pun alasannya. Namun seandainya tidak banyak facade pun, kita punya blindspot yang dilihat oleh sorot mata orang lain, namun tak kita sadari. Dan kita punya sisi yang disebut ketaksadaran.

\section{Gairah Hidup dan Etika}

Ketaksadaran itu berkaitan dengan gairah hidup (elan vital) yang mengge- legak. Sigmund Freud menafsirkannya sebagai libido yang selalu bergerak liar menuju ke kenikmatan (pleasure), namun ego mengaturnya agar gerak- annya dibuat dengan cara-cara yang dapat diterima secara sosial (sebagai- mana diinternalisasi dalam bentuk superego). Friedrich Nietzsche mengeja- nya sebagai "der Wille zur Macht” (hasrat akan kekuasaan). Meski manusia 


\section{Alois A. Nugroho, Etika Agama di Tengah Krisis Moral Bangsa \\ DOI: - \\ http://www.konfrontasi.net/index.php/konfrontasi2}

mestinya beyond good and evil, yang baik yang menjadi tujuan kesem- purnaan etika Nietzschean ialah yang mengejar kekuasaan. Ernst Cassirer mengejanya sebagai hasrat untuk mengetahui (mengenal), untuk menata lingkungan, melalui aksi penandaan, sehingga hidup manusia adalah hidup sebagai animal symbolicum. Charles Darwin menafsirkannya sebagai hasrat untuk bertahan hidup (struggle for survival). Whitehead mengritik Darwin dan mengajukan tafsirannya bahwa gelegak hidup itu bertujuan untuk "to keep alive, to live well and to live better".

"Well" dan "better" berkaitan dengan "good". Oleh karena itu, etika Paul Ricoeur mengatakan bahwa struktur teleologis dari hidup manusia terletak pada dimensi meta-etis yang melandasi dan memberi tenaga pada etika. Struktur teleologis itu ialah keterarahan kepada "yang baik", sebagaimana Whitehead terpukau dengan apa yang oleh Plato sudah dikenal sebagai "the idea of the good". Lepaskan etika dari struktur teleologis ini, maka yang tinggal hanyalah formalisme kosong, basa-basi yang tawar dan basi, prose- dur yang baku dan mati. Tak ada gairah, tak ada cinta, tak ada keindahan yang menjadi ruhnya. Itu banalitas, kata Hannah Arendt. Itu necrophily, kata Erich Fromm.

Gairah kehidupan yang tampak jelas dalam sajak-sajak penyair besar Indo- nesia ini, 10 dan yang oleh Alfred North Whitehead disebut creativity atau ongoingness, dan oleh Henri Bergson disebut elan vital, memiliki struktur teleologis, terarah (intentional) kepada "yang baik". "Yang Baik" mengun- dang dan membisikkan panggilannya kepada gairah hidup. Dia adalah yang "duduk mendekat" (Upanishad) dan mengeja jalan-jalan ke arah kebaikan (marga dari catur arya satyani). Paul Ricoeur, seorang failasuf, memerinci arah gairah hidup ini sebagai kerinduan untuk "hidup baik, bersama dan untuk orang lain, dalam institusiinstitusi yang adil".

"Yang baik" mengubah chaos menjadi kosmos, gairah yang chaotic, yang tak bernama dan tak berkata, menjadi orientasi yang dapat dirinci melalui "firman" atau "sabda". Di sinilah barangkali konsep "etika agama" harus diletakkan. Keterarahan kepada hypergood12 diperinci ke dalam norma- norma atau kewajiban-kewajiban moral. Dalam bahasa Ricoeur, tataran ini disebut tataran deontologis. Bahkan tataran ini pun tidak sepi dari diskusi dan interpretasi, yang berkaitan dengan teologi atau ilmu kalam. Dalam denominasi religius yang sama pun, apa yang wajib, yang dilarang dan yang boleh tidak selalu menimbulkan kata sepakat. Muncul fenomena sosial dan historis yang disebut mazhab atau schools.

Namun demikian, betapa pun majemuknya tafsir dan mazhab atas hyper- good ini, sudah tersedia orientasi untuk mengejar perfeksionisme moral atau "kesempurnaan hidup". Adalah masuk akal semata bila manusia mengarah- kan hidupnya kepada "yang baik" sebagaimana diajarkan oleh doktrin "kesempurnaan hidup" yang dianutnya. Kemasukakalan inilah yang meng- inspirasi John Rawls untuk menyebut sikap setiap orang saleh yang meng- arahkan hidupnya betul-betul kepada "kesempurnaan hidup" sebagai sikap yang "rasional". Label "rasional" ini cukup menarik, karena biasanya per- feksionis moral semacam ini malah kita sebut sebagai "tidak rasional".

Mengapa agama-agama dunia yang sudah menggarami wilayah Nusantara selama tak kurang dari 19 abad seperti tak berdaya menghadapi krisis moral Indonesia modern?14 Pertama, ada kemungkinan manusia Indonesia tidak betul-betul menghayati struktur teleologisnya dan secara "rasional" menga- rahkan hidupnya kepada hypergood sebagai comprehensive doctrine atau ajaran tentang "kesempurnaan hidup" mereka. Kaitan antara ritusritus dan norma-norma "agama" dengan hypergood kurang dilihat dan didalami. Kedua, barangkali juga kepatuhan terhadap norma-norma deontologis hanya "formalistis", artinya 
Konfrontasi: Jurnal Kultur, Ekonomi dan Perubahan Sosial, 3 (1) Januari 2016, 24-28

P-ISSN: 1410-881X (Print)

\section{Alois A. Nugroho, Etika Agama di Tengah Krisis Moral Bangsa \\ DOI: - \\ http://www.konfrontasi.net/index.php/konfrontasi2}

hanya patuh bila dilihat oleh "sorot mata orang lain", tidak benar-benar didorong oleh gairah "cinta kepada yang baik".

Dua kemungkinan di atas membawa kita kepada satu kata kunci lain dari etika Ricoeur, yakni "imputabilitas", yang dalam bahasa buku teks etika kurang lebih berbunyi "otonomi moral" (yang dilawankan dengan "hetero- nomi moral").15 Imputabilitas berarti kemampuan atau kapabilitas untuk mengebawahkan diri, dalam arti mematuhi, norma-norma moral yang disa- dari sebagai norma-norma yang disetujui oleh diri sendiri, begitu besarnya persetujuan itu seakan-akan malah norma-norma itu dipasang sendiri bagi diri sendiri.16 Gairah kehidupan yang mewujud dalam kerinduan kepada "yang baik" dan kemampuan "rasional" untuk melihat kaitan antara kepa- tuhan kepada norma-norma dan terwujudnya hypergood17 ini memperkuat kemampuan insani yang disebut "imputabilitas" itu.

Kita pertama-tama diharapkan "mempersembahkan" bukan kurban bakar- an, bukan kambing atau sapi, melainkan diri kita sendiri. Artinya, kita me- menuhi panggilan "yang baik" bukan sebagai kambing atau sebagai manusia sejauh dia makhluk hidup, tetapi sebagai manusia yang memiliki kesadaran, kemampuan refleksi, rasionalitas, perasaan keindahan, kerinduan, cinta.18 Demikianlah, kalau morallitas agama yang deontologis itu diamalkan berda- sarkan motif teleologis berupa kerinduan pada "Yang Baik", apa yang disebut "etika agama" akan secara efektif terwujud dalam perilaku masyarakat, tidak sebatas pada formalitas dan perilaku ritualistis saja.

Yang juga penting adalah pokok tentang apa yang diistilahkan oleh Ricoeur dengan "solicitude", kepedulian terhadap orang lain. Dalam realisasi hyper- good itu, manusia melihat bahwa "yang baik" juga terefleksikan dalam kepe- dulian terhadap orang lain. Kepedulian terhadap orang lain ini bukan hanya terbatas pada lingkungan dekat yang dikenal akrab dan memiliki hubungan afektif langsung, melainkan juga bahkan menggapai mereka yang anonim, yang tak dikenal, yang hidup tak hanya pada masa kini, tetapi juga pada masa akan datang. Rasionalitas, kata Peter Singer, juga ditandai oleh melu- asnya lingkaran pihakpihak yang dipertimbangkan atau dipedulikan (moral recipients) dalam deliberasi moral,19 tidak hanya sekeluarga, sedarah, sesu- ku, seumat, separtai, dan semacamnya. Bela rasa dan kesediaan mempe- dulikan orang lain ini bahkan menggapai pihak-pihak yang lazimnya dianggap "musuh", seperti dikisahkan dalam perumpamaan "Orang Samaria yang berbelas kasih" (the good Samaritan).

Krisis moral bangsa dapat dikatakan berhubungan dengan ketakmampuan kita untuk melakukan "expanding the circle" dalam deliberasi moral ini. Terlalu simplistis, bila kita menghakimi peselingkuh dan koruptor serta penyalah guna jabatan sebagai orang-orang egois semata-mata. Mereka biasanya juga orang-orang yang memiliki solicitude. Rasionalisasi atau bukan, adultery sering juga dipicu oleh dorongan untuk memberi "minum" orang lain yang "dahaga", memberi "makan" orang lain yang "lapar". Koruptor dan penyalah guna jabatan juga orang-orang yang berniat baik untuk "mencukupi" keluarga yang biasanya juga berarti "keluarga besar" (extended family). Para pengusaha yang melakukan tindakan-tindakan tidak etis sering juga melakukannya untuk kepentingan para pemegang saham, bahkan para pekerja. Politisi yang tidak peka terhadap kemiskinan rakyat, sering juga didorong oleh niat untuk memasok dana bagi partainya. Akan tetapi, tetap bisa kita katakan bahwa mereka semua mengidap myopia moral. Horison solicitude mereka amat sempit. Mereka hanya mempertimbangkan kebaikan bagi lingkungan dekat. Horison mereka tidak men- jangkau wilayah "bangsa" atau "kepentingan nasional", apalagi "umat manu- sia", "masa depan umat manusia", kepedulian ekologis." 
Konfrontasi: Jurnal Kultur, Ekonomi dan Perubahan Sosial, 3 (1) Januari 2016, 24-28

P-ISSN: 1410-881X (Print)

\section{Alois A. Nugroho, Etika Agama di Tengah Krisis Moral Bangsa}

DOI: -

http://www.konfrontasi.net/index.php/konfrontasi2

\section{Catatan Penutup: Tataran Kebijaksanaan Praktis}

Skema etika Ricoeur sebenarnya masih mengenal satu tataran lagi, yaitu yang disebutnya tataran "phronetical" (dari bahasa Yunani yang dipakai oleh Aristoteles, phronesis, katakanlah itu keadaan proporsional, tak lebih dan tak kurang) atau yang oleh Taylor disebut "practical wisdom". Dalam kenyataan, jarang kita dihadapkan pada hanya satu norma deontologis yang perlu dipertimbangkan untuk diterapkan. Biasanya ada lebih dari satu, sehingga kita perlu mengembangkan kemampuan untuk menemukan "takaran" yang tepat dalam pelaksanaan norma-norma itu. Situasi-situasi yang melibatkan dimensi moral itu pun tidak selalu persis sama, sehingga perlu pula dikembangkan kemampuan untuk "menakar situasi".

Akan muncul pentingnya istilah lain di samping "rationality" dalam kaitan- nya dengan hypergood tadi, yakni istilah reasonableness yang dikembang-kan oleh para pemikir Rawlsian. Kalau rasionalitas berhubungan dengan "kesempurnaan", perfeksionisme, "reasonableness" dalam praktik berhu- bungan dengan "proporsionalitas" tadi.21 Dalam konteks John Rawls, istilah ini justru muncul dalam kaitannya dengan peranan kosa kata yang berasal dari "etika agama" dalam forum publik politik yang resmi. Bagi Rawls, diskursus dalam forum publik politik resmi (eksekutif, legislatif, yudikatif) wajib menggunakan "penalaran publik" dan bahasa yang tidak menggu- nakan "kosa kata agama" tertentu, karena hal itu akan memarginalkan sebagian warga negara yang tidak familiar dengan "penalaran" dan "kosa kata" bersangkutan. Namun pada tingkat civil society, etika agama berpe- ranan penting. Dan republik demokratis yang sehat dan kuat ialah republik yang ditopang oleh civil society yang sehat dan kuat, artinya republik dimana setiap warga negara berupaya hidup sesuai dengan hypergood yang diajarkan oleh agama masing-masing.

\section{Bibliografi}

Freeman, Samuel, Rawls (New York: Routledge, 2007).

Rawls, John, Political Liberalism (New York: Columbia University Press, 2005).

Ricoeur, Paul, Reflections on the Just (translated by David Pellauer), (Chicago: University of Chicago Press, 2007).

Singer, Peter, The Expanding Circle: Ethics, Evolution and Moral Progress

(Princeton: Princeton University Press, 2011).

Taylor, Charles, Sources of the Self (Cambridge: Cambridge University Press, 2003).

Whitehead, Alfred North a.b. Alois A. Nugroho, Fungsi Rasio (Yogyakarta: Kanisius, 2001).

Whitehead, Alfred North a.b. Alois A. Nugroho, Mencari Tuhan Sepanjang Zaman (Bandung: Mizan, 2009). 